\title{
The Spatial Economy of North American Trade Fairs
}

\author{
Harald Bathelt \& Ben Spigel
}

Version Post-print/accepted manuscript

Citation Bathelt, H., \& Spigel, B. (2012). The spatial economy of North

(published version) American trade fairs. The Canadian Geographer/Le Geographe Canadien, 56(1), 18-38.

\section{Copyright / License}

Publisher's Statement

The version of record [Bathelt, H., \& Spigel, B. (2012). The spatial economy of North American trade fairs. The Canadian Geographer/Le Geographe Canadien, 56(1), 18-38.] is available online at: http://onlinelibrary.wiley.com/doi/10.1111/j.1541$\underline{0064.2011 .00396 . x / \text { full }}$

Always cite the published version, so the author(s) will receive recognition through services that track citation counts, e.g. Scopus. If you need to cite the page number of the TSpace version (original manuscript or accepted manuscript) because you cannot access the published version, then cite the TSpace version in addition to the published version using the permanent URI (handle) found on the record page. 


\section{The Spatial Economy of North American Trade Fairs}

By

Harald Bathelt (Corresponding author)

University of Toronto, Department of Political Science and Department of Geography \& Program in Planning, Sidney Smith Hall, 100 St. George Street, Toronto ON M5S 3G3, Canada and Zijiang Visiting Professor, Department of Urban and Regional Economics, East China Normal University, Shanghai, China E-mail: harald.bathelt@utoronto.ca, URL: http://www.harald-bathelt.com

and

Ben Spigel

University of Toronto, Department of Geography \& Program in Planning, Sidney Smith Hall, 100 St. George Street, Toronto ON M5S 3G3, Canada

E-mail: ben.spigel@utoronto.ca

Through a study of trade fairs, this paper illustrates that relational approaches to economic geography are not limited to the sphere of economic and social relationships. These relationships are influenced by and, in turn, shape material realities, such as specific infrastructure and the labor market, in a reflexive manner. Trade fairs are "relational events" that bring together regional, national, and often international producers, users, suppliers, and other agents of a value chain or technology field for the purpose of exchanging knowledge about technological and market developments, building partnerships, and maintaining existing networks through learning by interaction and observation. However, these events are also situated in space and time, grounded in the contexts of particular industries, trade patterns, public and private investments, as well as the economic geographies of places. Focusing on North America, this paper presents and analyses data on the economic geography of trade fairs and their regional economic impact (number of events, exhibitors, attendees, exhibition space). It explores regional trade fair patterns and dynamic changes in major trade fair cities by emphasizing the role of history and industry context.

Keywords: North America, relational economic geography, trade fairs, regional economic impact 


\section{Introduction}

European trade fairs have long been the center of economic and cultural exchange places where, already in medieval times, products were traded between national or international traders and local consumers. They developed as a consequence of highly regulated and segmented territories that were characterized by rigid trade restrictions (Allix, 1922; Fuchslocher and Hochheimer, 2003; Rodekamp, 2003). Only during certain days of the year, often related to Christian holidays, non-local traders were permitted to sell their products to the population of the respective urban areas. These temporary markets (Rinallo and Golfetto, 2011) later developed into events through which market and technology trends, as well as information about economic and political regulations, were systematically discussed and disseminated. Even during the medieval time period, however, trade fairs were much more than just marketplaces. Two criteria particularly influenced the geographical distribution of European trade fairs: (a) the existence of a production core in the surrounding region and (b) proximity to intersecting trade routes (e.g. Boggs, 2005). Despite this, the geography of trade fair activities did not remain static, but underwent significant changes over time. To understand these geographical shifts, we must keep in mind that most such events were normally not deeply embedded in the urban fabrics that hosted them (Allix, 1922). Shifts in trade fair locations were influenced by political hegemonies, disparities in economic development, innovation cycles, and shifting markets. In the $20^{\text {th }}$ century, trade fairs increasingly shifted their focus from places for finalizing contracts and sales to those where important information and knowledge about product characteristics, innovations, and market trends were exchanged (Borghini et al., 2004; Maskell et al., 2006). 
While substantial information about the history and geography of European trade fairs exists (Allix, 1922; Fuchslocher and Hochheimer, 2003; Rodekamp, 2003), North American fairs developed much later and have not been studied as extensively as their European counterparts. Consequently, less is known about the geography of trade fair activity in the U.S. and Canada, the attendance of such events by exhibitors and visitors, and the dynamic changes in the trade fair business (for an exception, see Zelinsky, 1994).

To address this research gap, this article has two goals: First, we aim to investigate the economic geography of North American trade fairs by studying characteristics such as the number and size of trade fairs in terms of attendance and exhibition space in U.S. and Canadian cities. ${ }^{1}$ Second, we aim to explore and quantify changes in the North American trade fair industry. This is particularly important as these events are not only "relational places" where information and knowledge are circulated and disseminated through intensive inter-firm communication; they are also associated with physical places and materialize in the form of a local support industry that provides local jobs and incomes. Our research contextualizes the changes in the geography of trade fairs over the past forty years and identifies the connections between these events and North America's broader economic geography.

Using this as a starting point, our argument is structured as follows: The next section provides a conceptual discussion about the role of trade fairs in the global knowledge economy and their relational geographies. Here, we also discuss the research methodology and note the limited availability of reliable data on North American trade fairs. The paper then discusses growth of trade fairs in North America in the post-World War II period more broadly. The section that follows focuses on recent structures and trends since the turn of the millennium, before the rise of trade fairs in Chicago, Las 
Vegas, and Toronto is investigated to explore important trajectories in the development of major trade fair centers. This allows us to demonstrate how different trajectories of major trade fair centers have become established over time in a relational manner through reflexive interrelationships between trade fair development, historical structures, and infrastructure investments. Finally, the paper draws some conclusions about the future of trade fairs in an increasingly volatile economy.

\section{Relational Geographies of Trade Fairs}

Recent work argues that trade fairs - especially international ones - have become a core element of new relational geographies (Bathelt and Schuldt, 2010). Trade fairs no longer focus on the exchange of goods and the signing of sales contracts (although still important), but instead are catalysts of knowledge circulation in a value chain through which knowledge and understanding about industries and technologies is created and disseminated over distance. Trade fairs can be viewed as "relational places" that emphasize the role of communication and interaction in understanding and explaining economic structures. This fits well into the context of recent work on relational economic geography which is characterized by a number of commonalities, including (a) its focus on economic agency in space instead of spatial representations, (b) micro-level reasoning, (c) an institutional focus in analyzing stabilizations of economic practices, and (d) the analysis of the effects of globalization on economic organization (Yeung, 2005; Bathelt, 2006). Trade fairs specifically focus on bringing together members of a particular value chain or industry to display new products to potential suppliers and customers, as opposed to conventions and congresses where the emphasis is placed on knowledge acquisition through seminars and lectures. ${ }^{2}$ 
The relational character of trade fairs has been acknowledged in studies that characterize trade fairs as temporary assemblages of human beings (Zelinsky 1994), periodic events in the social economy (Norcliffe and Rendace, 2003), temporary clusters (Maskell et al., 2004), cyclical clusters (Power and Jansson, 2008), or temporary markets (Rinallo and Golfetto, 2011), with organized proximity for interaction (Rallet and Torre, 2009). ${ }^{3}$ Trade fairs provide information about global developments in markets and technologies and are key for making personal contact with potential customers and suppliers. As opposed to earlier work, recent studies emphasize the knowledge-based character of these events (Borghini et al., 2006; Maskell et al., 2006; Bathelt and Schuldt $2008 ; 2010)$ and describe how certain international trade fairs have become central nodes that connect the global political economy (Bathelt, 2011), creating a microcosm of an industry for a limited period of a few days (Rosson and Seringhaus, 1995).

Trade fairs generate opportunities for knowledge creation, networking, product branding, and market development beyond the local scale. Face-to-face (F2F) meetings with other participants enable firms to systematically acquire information and knowledge about the technological and strategic choices of competitors, suppliers, and customers (Borghini et al., 2004). During trade fairs, information concerning industry-wide trends and ideas - as well as all sorts of news and gossip - flow between spatially and temporally clustered participants (Maskell et al., 2006). Agents benefit from integrational and informational cues developed through repeated, intensive, and often short F2F encounters which lead to a specific communication and information ecology, referred to as "global buzz" (Bathelt and Schuldt, 2010). ${ }^{4}$ Global buzz involves unique processes of knowledge dissemination and creation through interactive learning and learning by observation (Maskell et al., 2006). It is related to the dedicated co-presence of global 
supply and demand; intensive, temporary F2F interaction; a variety of possibilities for observation; intersecting interpretative communities; and the formation of multiplex relationships (see also, Borghini et al., 2006). For many participants, the value of the trade fair is particularly in this buzz-based learning rather than the actual sales or purchases made.

International fairs bring together leading and less well-known agents from an entire industry or technology field for the primary purpose of exchanging knowledge regarding present and future developments of their industry, centered on displays of products, prototypes, and innovations. This allows actors to develop an overview of market trends and provides a myriad of opportunities to make contact, ask questions, and engage in F2F communication with other agents in the same value chain or industry (Rosson and Seringhaus, 1995; Sharland and Balogh, 1996; Godar and O'Connor, 2001; Prüser, 2003). Firms that regularly attend these fairs are able to find suitable partners to complement their needs, establish trust with distant partners, and undertake the first steps toward the development of durable inter-firm networks in research, production, and marketing. Exhibitors and visitors benefit enormously from the variety of formal and informal meetings held with a diverse array of agents (Borghini et al., 2006; Entwistle and Rocamora, 2006).

A relational interpretation of trade fairs, however, needs to go beyond a discussion of flows and networks. It suggests that economic action is not only shaped by socio-institutional relationships but also influenced by outcomes and structures related to former decision-making and interaction, albeit not in a deterministic manner (Bathelt and Glückler, 2011). Therefore, a relational analysis clearly builds on evolutionary perspectives. This allows us to take into consideration how material geographies of 
buildings and infrastructure affect economic action and interaction, and how the results of this interaction (for instance, investments in new trade fair centers), in turn, impact the use and further development of material geographies in a relational manner. The final use of a new exhibition space is, for instance, not a priori determined. Whether it will become a conference or convention center, a place for local or international exhibitions and trade fairs, a shopping mall, or a place for sports and recreational activities in the end depends on the revenue flows it produces, and the way how potential users and their clients use this space and what other options they have, or how investors react to these patterns. As such, there is a connection between traditional analyses of sites and locations and recent investigations of knowledge flows in economic geography.

From this, it becomes clear that trade fairs are not only places where information and knowledge are circulated through intensive inter-firm communication. They also materialize in place and are associated with these places in grounded ways through money flows, jobs in services and catering, and they establish a trade fair support economy within the urban fabric. The additional income and employment this produces can make a substantial contribution to the overall economy (Schätzl et al., 1993). In the case of Germany - a leading country in the international trade fair business - trade fairs attracted an average of 26.6 million visitors and 331,000 exhibitors per year between 2005 and 2008 . They generated $€ 12.1$ billion in direct economic effects (including investments of the trade fair organizers), plus an additional $€ 11.4$ billion of indirect effects. In terms of the labor market, these events created a total 226,300 jobs in Germany (AUMA, 2009c).

At the urban level, these events provide a substantial economic stimulus. In Munich, for instance, trade fair exhibitors and visitors produced direct and indirect 
economic effects of $€ 2.2$ billion per year between 2004 and 2007, creating almost 22,000 jobs in the city-region (Penzkofer, 2008). Vancouver authorities estimated that, in 2007, trade fair attendees and convention visitors generated a combined \$584 million (CAD) in direct spending, leading to over $\$ 1.0$ billion (CAD) of secondary economic output and generating more than 13,000 jobs (Tourism Vancouver, 2007). In general, these events support the local hotel, leisure, and entertainment sector and generate important multiplier effects for cities. Moreover, trade fairs connect urban economies with wider national or international industries and production chains, helping to establish, maintain, and extend strategic knowledge pipelines that both originate from and are directed to these places (e.g. Malecki and Poehling, 1999; Bathelt, 2011).

Trade fairs clearly demonstrate the reflexive relationship between non-material and material geographies. They are manifestations of the continued need for temporary proximity and F2F contact even within a globalized economy. At the same time, they have localized material outcomes in the "real geographies of places". This demonstrates the continued need to study relational phenomena not only in the context of dense networks of social relationships, but also how these phenomena touch down in particular places and create or alter material social and economic geographies. While recent studies have emphasized the relational character of trade fairs in the knowledge economy (Borghini et al., 2004; Maskell et al., 2006; Bathelt and Schuldt, 2010), this paper focuses on their material base in terms of the geographical distribution and size of these events, and their underlying investment geographies.

Given the substantial importance of trade fairs for knowledge flows and network building, as well as local economic development and job creation, it is surprising how little is known about the size, structure, and development of these events in North 
America. In our attempt to fill this knowledge gap, we study the structure of these events in the most important North American trade fair cities and the characteristic trajectories in the development of leading trade fair cities. In drawing on the cases of Chicago, Las Vegas, and Toronto, we demonstrate how historical structures, investment decisions, and economic relationships have triggered different paths of trade fair development and how this has, in turn, impacted further investment decisions.

The major problem of such an analysis is the lack of robust and reliable data on North American trade fairs. ${ }^{5}$ This paper presents a major effort to collect, check, and cross-examine existing data, and to present it in a careful analysis that is - necessarily somewhat descriptive in character. We use a variety of methods to characterize the structure and changes of the industry. The experiences of Chicago, Las Vegas, and Toronto are examined through both historical documents and interviews with key informants. ${ }^{6}$ Developments in the industry from 1960 to 1990 are examined based on Zelinsky's (1994) study of trade fairs in the U.S. To study the current state of the trade fair economy in the U.S. and Canada, we employed different datasets from the Center for Exhibition Industry Research (CEIR) - a U.S.-based industry group that monitors North America's trade fair industry. To analyze recent trends, we use two main sources of trade fair data: The first is the so-called CEIR Index (CEIR, 2005; 2009) which provides information about trends in the number, attendance, size, and revenues of North American trade fairs. This dataset presents estimates from a representative sample of trade fairs - the so-called CEIR Index Events - consisting of 219 events in 2001 and 436 events in 2007. The second data source records events in the 25 largest North American trade fair cities, broken down by industry sector, size of trade fair, and location. The detailed data from 2005, which is based on a census of the population of trade fairs that 
year, is used here in conjunction with data from the CEIR Index Events from 2001 to 2007 to project the total number of fairs each year by industrial sector (TSW and CEIR, 2005; CEIR, 2009). These datasets represent the most detailed and comprehensive information about trade fairs available in the U.S. and Canada and allow for an analysis of the structures and trends of such events in North America.

\section{Post-World War II Trade Fair Growth}

Zelinsky's (1994) article "Conventionland USA" remains the foremost work on the spatial distribution of trade fairs in the U.S., showing that the simultaneous diversification and specialization of the post-World War II economy, combined with advances in transportation technologies, dramatically increased the importance of trade fairs since the 1960s, moving them from simple venues for product demonstration to their current role as critical nodes in global economic processes (Rosson and Seringhaus, 1995; Bathelt, 2011).

Shifts in the geography of North American trade fairs were primarily driven by changes in the economy and associated infrastructure investments. In 1960, trade fairs were heavily clustered in the Manufacturing Belt (Figure 1(a)). The largest trade fair cities at this point in time were embedded in the road, rail, and air networks, and had large numbers of local industrial firms looking for opportunities to demonstrate their products. Thus, trade fairs were clustered in cities like Chicago, New York, or Philadelphia. Other important trade fair cities included Washington, DC and Miami where capitol attractions and leisure activities attracted fairs and attendees (Zelinsky, 1994). 
By 1990, these patterns had shifted substantially in response to changes in the American economic geography (Figure 1(b)). These dynamics reflect a dramatic shakeup resulting from the decline of the Fordist economy in traditional industrial centers and the rise of the Sunbelt (e.g. Perry and Watkins, 1977). The most prominent change between the 1960s and 1990s was the movement of trade fairs away from the industrial Northeast and towards Sunbelt and Southwest cities like Las Vegas (which jumped in trade fair ranking from $20^{\text {th }}$ to $4^{\text {th }}$ place) and New Orleans (which moved from $16^{\text {th }}$ to $2^{\text {nd }}$ place). Older industrial cities with aging, first generation trade fair centers lost ground to newer destinations in the Sunbelt (Zelinsky, 1994). An important factor influencing the location of trade fairs was associated with costs, which differ greatly between small and large urban centers, and between places in the Sunbelt and Rustbelt (AUMA, 2009a). In general, unions had and still have a strong impact on trade fair activities as most convention and exhibitions centers have contractual agreements with them. Wages for specialists, which are hired to build the exhibits, also differ greatly. According to AUMA (2009a), a carpenter working at a trade fair in Louisville, KY earned about $\$ 45$ per hour while the same rate in New York was almost $\$ 150$ (and \$260 on weekends). Nonetheless, this change did not have the character of a complete shift to the South. Northeastern and Mid-Atlantic cities like Boston $\left(10^{\text {th }}\right.$ in 1990$)$ and New York City $\left(11^{\text {th }}\right.$ place $)$ remained important nodes in the trade fair economy (Zelinsky, 1994).

The mobile nature of trade fairs helps explain this trend: Small trade fairs can choose between hundreds of different urban locations. The choice may depend on the participants' access to a city or the potential for leisure pursuits (Law, 1987). Only the largest trade fairs are restricted to large urban areas with major facilities that can accommodate them. The mobility of trade fairs allows for gradual shifts in the spatial 
distribution: events gravitate towards regions and cities that are growing, away from those that are shrinking.

Figure 1(c) completes this trend over the study period. Although the shift from the Northeastern to Southern and Western cities was most prominent between 1964 and 1990 with a southwestern shift of the mean center of trade fairs by about 540 kilometers (Figure 1(a) to 1(b)), further significant changes occurred after this period. The shift between 1990 and 2005 was not quite as strong, with a movement of the mean center only by about fifty kilometers to the South, as the substantial gains of states like California and Texas balanced out the remarkable rise of Toronto, Ottawa, Montreal, and Vancouver in Canada (Figure 1(b) to 1(c)). This clearly shows that the concentration of trade fair activity in the U.S. Manufacturing Belt dissipated by 2005 , while prominent new clusters of trade fair activity developed in the California/Nevada and Texas/Louisiana corridors, as well as in major Canadian cities.

The continued shifts in the top 25 trade fair cities suggest that trade fair activities are not locked into static geographies. While several large cities like New York and Chicago consistently retained their position in the rankings, the correlation between population and number of trade fairs declined from 0.76 in 1960 to 0.12 in 2005 . This demonstrates the success that smaller cities like Orlando and Las Vegas have had in attracting a substantial number of trade fairs as a consequence of large investments in their infrastructure. As a result, the geography of trade fairs is not merely a function of city size. 
Overall, the U.S. overshadows the Canadian trade fair industry despite the emergence of Toronto and Montreal as important trade fair cites in the 1970s and 1980s (AUMA, 2002). Canadian cities are disadvantaged when competing for international trade fairs because of the relatively small size of the Canadian market. Most international exhibitors focus on U.S. trade fairs, knowing that their Canadian clientele will likely attend these fairs. The same cannot be said for American firms participating in Canadian fairs. As a consequence, most Canadian fairs have a primary regional/national focus, with few exceptions such as Calgary's Global Petroleum Show or Fort McMurray's Oil Sands Trade Show, which are global in character. ${ }^{7}$

The post-World War II shifts in the North American economy and increased competition between North American cities contributed to trends towards image-making in urban centers. Selling the city as a trade fair destination has become a significant element of city branding and economic development (Bradley et al., 2002). Trade fairs are valuable both for the employment and direct revenue they generate - trade fair attendees spend two to three times more than leisure tourists (Law, 1987) - but also because cities use trade fairs to construct images that encourage future visits and investment (Opperman, 1996; Opperman and Chon, 1997). Although the actual economic impact of trade fairs is frequently pointed out as a rationale to host such events, the supposed benefits of business tourism sometimes appear to be overestimated and the costs underestimated (Sanders, 1992; 2002). ${ }^{8}$ While the immediate economic benefits of trade fairs, such as direct and indirect job creation, are localized, other benefits, especially the resulting knowledge flows and circulation, are broad and have a national or global component. 
Major trade fairs are important because they connect small regional firms with national or international markets (Wilkinson and Brouthers, 2006; Ramirez-Pasillas, 2008). Both large and small firms benefit from being part of the localized microcosm of their industry during major fairs (Kijewski et al., 1993; Rosson and Seringhaus, 1995; Power and Jansson, 2008). In the next section, recent structures and trends of the North American trade fair business are presented and interpreted as evidence of continued growth, rather than stagnation or decline.

\section{Recent Structures and Trends of North American Trade Fairs}

Although some reports have questioned the importance of trade fairs in the Internet Age (Backhaus and Zydorek, 1997; Moellenberg and Teichmann, 2000), this section presents evidence of the continued growth of these events in major urban centers in the U.S. and Canada - contrary to what is sometimes assumed. Despite the development of real-time video conference systems and other telecommunications technologies, the growth of trade fairs over the past decade demonstrates the continued need for periods of intense F2F interaction in the business cycle. Overall, the number of events in the top 25 North American trade fair cities has increased from 4,521 in 2001 to 7,753 in 2007. In the same time period, the average number of exhibitors and attendees per event also increased by $31 \%$ and $25 \%$, respectively (CEIR, 2005; 2009). This growth is remarkable, since the costs of trade fair attendance are significant, associated with extensive scheduling and shipments of materials and people. The growth in the number of events is clearly related to the high value of F2F-based encounters and opportunities for strategy development and innovation that arise from this buzz. This involves unique possibilities to inspect new product and technology developments in person, as well as opportunities of learning by 
interacting with existing or potential partners, learning by observing competitors, and learning by inspecting other exhibits (Bathelt and Schuldt, 2008; 2010).

While this suggests that trade fairs continue to increase in importance in North America, we should be cautious in drawing conclusions about this growth. The entire industry experienced a decline in the wake of both the post dot-com recession and the 9/11 shock, resulting in a downturn that lasted at least until late 2002. Moreover, the number of trade fairs in 2001 was already depressed due to the collapse of the "new economy" bubble and the IT fairs associated with it (Breiter and Hahm, 2006). The subsequent increase was due to both strong economic growth and a recovery from previous crises. Although some observers expected longer-term stagnation of trade fair activities (AUMA, 2004a; 2009a), many events and most sectors experienced substantial growth in the first decade of the new millennium as discussed below. ${ }^{9}$

Depending upon which definition is used, the U.S and Canada host between 5,000 and 13,000 trade fairs per year (AUMA, 2009a). CEIR (2005) estimates that approximately 10,000 events in the mid 2000s were business-to-business (B2B) fairs, which attracted about 60 million attendees and 1.5 million exhibitors, generating direct revenues of $\$ 10.3$ billion. This indicates that trade fairs are a significant element in the overall North American economy and of specific importance to the large urban trade fair centers. The economic impact of trade fairs, derived from payments to direct and secondary employment and the local expenditures of delegates and exhibitors, was estimated to be as high as $\$ 140$ billion in 2003 (Lee and Back, 2005).

Figure 2 illustrates the growth in the number and average size of trade fairs between 2001 and 2007. The data suggest a strong increase in both the number and size of events, with temporary interruptions in 2002 and 2005. Overall, the average size of a 
trade fair increased by 47\%, from 115,000 square feet in 2004 to over 165,000 square feet in 2007. Although major U.S. and European trade fairs had, on average, similar numbers of exhibitors, U.S. fairs fell far behind in terms of attendance. The 200 largest trade fairs and exhibitions in the U.S. had about 975 exhibitors per event in 2002, compared to about 1,130 and 610 exhibitors per international fair in Germany and Italy, respectively (2002 to 2005). Interestingly, the 200 largest trade fairs in the U.S. had on average about 21,000 visitors, while international trade fairs in Germany and Italy averaged about 65,000 to 70,000 visitors per event (Kresse, 2003; Maskell et al., 2004; CERMES, 2005).

[Figure 2 about here]

The CEIR Index breaks trade fairs into twelve industrial sectors. Figure 3 tracks the growth and decline of the number of trade fairs (a), exhibitors (b), and attendees (c) in a selected number of industrial sectors. The data shows steady growth in terms of fairs, exhibitors, and attendees across most sectors. Trade fairs focusing on fields such as government, public service, and non-profit services; professional business services; or construction, building, home, and repair saw consistent growth in all metrics over the time period. Noticeable was the decline in the number of information technology and communcation fairs, from 929 in 2001 to 842 in 2007 . This sector was the only one with a decline in the number of events, which appears to be related to the earlier dot-com boom-and-bust period. The strongest growth in the number of fairs can be found in industrial/heavy machinery and finished business inputs (from 122 to 355) and in the professional business services industry (from 596 to 1,254). ${ }^{10}$ While exhibitor growth was gradual and consistent across all sectors - with the exception of the food and raw materials and science sectors, which experienced steep increases since 2005 (Figure 3b) - 
attendance levels grew in a relatively unequal manner across different sectors (Figure 3c). From a knowledge-circulation perspective, the overall intensification of trade fairs is a desirable development as larger fairs attract more exhibitors and attendees and provide a better environment for interaction among diverse participants, supporting the creation and dissemination of new knowledge and innovation (Borghini et al., 2006; Maskell et al., 2006).

[Figure 3 about here]

Table 1 shows that trade fair activities experienced substantial growth between 2001 and 2007 overall, but there was variation among sectors. Whereas average attendance per event increased by $39 \%$ in the construction, building, home, and repair sector, it decreased both in terms of exhibitors per event and average exhibition space. This meant fewer opportunities for firms to observe the market and their competitors. Again, we can see the effects of industry downturns on trade fairs, for instance the average information technology and communications fair declined by 12\% between 2001 and 2004, as the industry bottomed out. Sectors which are relatively new to trade fairs, such as professional business services, and more traditional segments, such as raw materials and science, both experienced strong growth in all indicators, suggesting a rising importance of trade fairs across the North American economy.

[Table 1 about here]

While Table 1 gives an overview of changes in the trade fair economy overall, the regional distribution of trade fairs in 2005 helps identify those cities that benefited most. Table 2 lists the top trade fair cities in North America in 2005. It distinguishes two types 
of fairs by business focus: B2B and Business-to-Consumer (B2C) fairs. B2B fairs are the usual type of trade fairs studied by researchers (with the notable exception of Penaloza, 2001), since these are events where value-chain-based learning processes take place. B2B fairs feature businesses interacting with and selling to other businesses. Participation is limited to a specialized subset of firms arranged in a value chain or technology field through high attendance fees or invitations. B2C fairs are based around advertising and selling goods to the general public though they are usually directed to a particular market segment. Consumer products, from mops to motorboats, are exhibited to the public in the hope of making direct sales on the exhibition floor. The primary goals of B2C fairs are immediate sales, branding, and market penetration, unlike B2B fairs where indirect sales, lead generation, and knowledge gathering are more important activities (Godar and O’Connor, 2000).

[Table 2 about here]

Tables 2 and 3 suggest that major North American trade fair centers/cities have diverse sectoral specializations. The data indicates few connections between the sectoral patterns of trade fairs and the cities' industrial specializations. This can be explained by two tendencies: First, trade fairs have, over time, displayed a strong dynamic. Second, North American trade fairs are less place-bound than European fairs. Many European trade fair centers historically developed around specialized manufacturing regions and, although changes in markets, technologies, and regulations led to relocations, these events had often stable locations for a certain time period. As will be shown below, the development of trade fairs in North America was different. Due to the importance of traveling salesmen in the industrial distribution system, and the significance of mobile 
conventions of technical communities that later attracted exhibits of products and technologies, national and international trade fairs in North America more often change their location from year to year (AUMA, 2004a; 2009a). Despite these general trends, however, we can identify some specialization trends in trade fair structures that can be linked to a city's economic strength or industrial history.

[Table 3 about here]

With 780 fairs in 2005, Las Vegas stands out as North America's dominant trade fair city (Tables 2 and 3). Its large-scale trade fair infrastructure, based around large publicly-owned convention centers and exhibition spaces, as well as hotel rooms and exhibition space in all the major casinos, gives the city the capacity needed to host several major events simultaneously (Jones, 2006; Yang, 2008). This developed infrastructure generates a competitive advantage in competing for large international trade shows and is closely linked to the city's overall tourism business.

Toronto, North America's second largest trade fair city, also stands out not just for the number of events it holds every year but for the high proportion of B2C fairs $(63 \%$ of all fairs). This is indicative of a structural difference between trade fairs in U.S. and Canadian cities. All Canadian cities exhibit a high proportion of B2C fairs (Table 2): 44\% in Vancouver, 43\% in Ottawa, and 39\% in Montreal. In contrast, the average proportion of B2C fairs in U.S. cities was $15 \%$. We have to exercise care not to interpret these numbers in terms of different demand- and supply-side patterns. On the one hand, the large number of consumer-oriented fairs in Canada is a reflection of the fact that it is more difficult to attract international businesses to the relatively small Canadian market. Therefore, a stronger focus on consumer-oriented fairs is almost a natural consequence. 
At the same time, this may also be a reflection of trade fair center capacity exceeding demand for B2B fairs, a gap filled in by a large number of B2C fairs (Interview with Direct Energy Centre Official, December 2009). The different structure of trade fair activities has substantial consequences on the national economic geographies of cities. The large proportions of $\mathrm{B} 2 \mathrm{C}$ fairs suggest that Canadian cities derive fewer economic benefits from trade fairs compared to U.S. cities, both in terms of direct trade-fair-related revenue, as well as placing the city within global flows of industrial and commercial knowledge.

Of the 21 top U.S. trade fair cities, 13 were located in the Southern and Western regions of the Sunbelt (e.g. Atlanta, Dallas, and Phoenix) and 4 cities are in or close to the Manufacturing Belt (New York, Chicago, Boston, and Minneapolis) (Figure 1). Following Zelinsky's (1994) analysis, this shows a continuation of the movement away from manufacturing-dependent regions. The rise of Southern and Western cities as major trade fair destinations is linked to their rise as industrial and commercial hubs throughout the 1970s and 1980s. As the cities' economies and population grew and became better integrated into national and international transportation networks, they developed into more popular destinations for trade fairs. Because Sunbelt and Western cities are less densely built, it is easier for them to establish new or expand existing trade fair centers and hotel capacity, as opposed to older Northeastern and Midwestern cities, where the space for large-scale trade fair center development and expansion is more costly and sometimes harder to find.

Figure 4 breaks down trade fair cities by size of event revealing interesting geographical patterns. Except for cities like Toronto, Vancouver, New York, and Minneapolis, the majority of fairs in all cities are smaller than 25,000 square feet (Figure 
4). These smaller trade fairs are often regional events that, according to our enquiry, typically do not attract a geographically diverse pool of attendees. ${ }^{11}$ Some cities, like Orlando, Ottawa, and Boston, specialize in these smaller fairs. This has implications for the ability of trade fairs in these cities to serve as effective sites of knowledge sharing and circulation for local firms, since smaller fairs primarily attract a local audience with few participants from outside the region or nation. As attendees come from a shorter distance and are likely to stay for a shorter time period, smaller fairs can be expected to generate less hotel, restaurant, and entertainment revenues, reducing their overall value to the city.

[Figure 4 about here]

Extra-local participation is vital for trade fairs to serve as sites of global buzz (Bathelt and Schuldt, 2008), and as "pipeline catalysts". Though there is no data on the distribution of international trade fairs in North America, large B2B fairs typically attract a substantial international audience, bringing in both increased tourism revenues and novel knowledge that is circulated throughout the event. Hosting large trade fairs requires that the trade fair centers, the local airport, and hotels all have sufficient capacity to handle a substantial international audience.

Table 3 reports the number of events in each city by sector and indicates the corresponding Trade Fair Location Quotient (TFLQ). ${ }^{12}$ A TFLQ above 1.20 means that the respective city hosts over $20 \%$ more trade fairs in a sector than the average city in our dataset. We use TFLQs of 1.20 and higher as an indicator of sectoral specialization patterns in North American trade fair cities. Although specialization patterns observed through this method are not overly prominent and cannot easily be explained by urban economic specializations, some exceptions exist. San Francisco, for instance - adjacent to 
Silicon Valley and home of many high-technology, telecommunications, and Internet firms - has a relatively high TFLQ of 2.2 for information technology and communications trade fairs. Chicago and Minneapolis - two Midwestern cities - have above average representations of industrial trade fairs, and all Texas cities in the dataset (Houston, Austin, and San Antonio) have TFLQs between 1.6 and 2.2 in raw materials and science trade fairs. This suggests that trade fair organizers - at least in these prominent cases - attempt to locate events in cities with a heavy concentration of their target industry. Washington, DC has a similarly high TFLQ for government and public sector oriented trade fairs. In contrast to Washington, DC, Ottawa has a relatively low proportion of government-related trade fairs. This is, in part, due to the substantially lower aggregate number of government-oriented trade fairs in Canada compared to the U.S. When recalculated only for Canadian cities, however, the TFLQ of governmentrelated fairs in Ottawa is 2.0, similar to that of Washington, DC. In sum, the TFLQs clearly reflect the importance of $\mathrm{B} 2 \mathrm{C}$ fairs in the Canadian trade fair economy (Table 2). Montreal, Vancouver, and Ottawa have TFLQs between 2.0 and 2.2 in the consumer services, sports, travel, entertainment, and arts sector while Toronto and Vancouver have TFLQs of 1.3 to 1.4 in the consumer goods and retail trade sector, which represent goods marketed directly to consumers at trade fairs (Table 3$).{ }^{13}$

\section{Development Paths of Trade Fairs in North America}

Both the data examined above and a historical analyses suggest that the relational and material geographies of North American trade fairs differ substantially from their European counterparts. Trade fairs in Europe developed much earlier than in North America and reflect to a larger degree traditional trade and industry patterns, major trade 
routes, as well as governmental regulations, social struggles, and wars. This resulted in segmented market patterns in Europe that only gradually changed over time (Allix, 1922). Shifts in trade fair locations were influenced by political power, disparities in economic development, innovation cycles, and shifting markets.

North American trade fairs emerged out the tradition of industrial exhibitions and conventions and agricultural fairs. One-time events, like the 1893 World's Columbian Exhibition in Chicago or the St. Louis World's Fair in 1904, and annual events, such as Toronto's Royal Agricultural Winter Fair, bring together buyers and sellers as well as serving as a platform for the demonstration of new inventions and products. The largest of these events helped local producers tap into global market places, even before improvements in communications and shipping technologies spurred globalized commerce. While these events were popular and important in the development of the modern global economy, they were not trade fairs as we understand them today. The historical world exhibitions were singular events designed to show off the achievements of industrial capitalism to the public without offering a formal venue for industrial suppliers and customers to meet and conduct business. Modern trade fairs serve as regular meeting places for commercial buyers, users, suppliers, and related multipliers to present new products and processes, make deals, and observe the changing nature of the industry.

The development of major urban trade fair centers in North America shows different patterns than those in Europe, starting later and taking place in a largely homogenous market. The following subsections illustrate three different growth trajectories that resulted in Chicago, Las Vegas, and Toronto. These cases illustrate how reflexive relationships between urban planning, industry needs, investment activities and 
strategies, and economic development gave rise to specific trajectories with varying material and relational geographies. Chicago's trade fair economy emerged in the 1950s out of its pre-existing industrial economy, while Las Vegas's trade fair infrastructure emerged at the same time, but based on a tourism strategy. Toronto's trade fair economy grew strong in the late 1970s and early 1980s through more explicit public-sectorcontrolled initiatives. The different paths of trade fair development demonstrate that trade fairs have become deeply embedded in both ongoing global economic processes and local politics.

\section{Chicago: From World Exhibitions to International Trade Fairs}

Like many other major industrial cities, Chicago has a long history of industrial exhibitions and trade fairs, starting in 1893 with the World's Columbian Exhibition - an international exhibition with 65,000 exhibits that attracted over 28 million visitors. The Century of Progress International Exhibition in 1933-1934 similarly showcased major scientific, industrial, commercial, and cultural advances of the day (Findling and Pelle, 2008). The city's substantial industrial base was able to use these exhibitions to demonstrate their products to the general public.

Chicago's role as a major trade fair destination did not begin, however, until 1958 with the construction of McCormick Place (Metropolitan Pier and Exposition Authority, 2011). Like most major trade fair centers in North America, McCormick Place was built with government funds and managed by a public corporation. Since its construction, McCormick Place underwent several stages of restructuring and expansion: the first in 1967 due to a fire that destroyed much of the original building and required an almost complete re-build, and several major expansions in 1977, 1984, 1991, and 2001. In 2008, 
McCormick Place had over 2.6 million square feet of exhibition space, making it the largest such space in North America, and one of the ten largest in the world (AUMA, 2004a; 2009b).

Several other cities close to the Manufacturing Belt, which opened major trade fair, convention, or exhibition centers in the 1960s, such as Boston and New York, experienced patterns of infrastructure modernization similar to Chicago. Many convention centers that were built in the 1960s were torn down in the late 1980s and early 1990s and replaced with newer, larger, and more technologically advanced facilities. While Chicago has not fully replaced McCormick Place, it built a new dedicated bus-only road linking the facilities with downtown Chicago to cut the commute time for attendees staying in the city's core.

Despite ongoing investments, the large size of McCormick Place has not prevented Chicago's loss of overall market share in the trade fair business since the 1970s. Chicago's position in Zelinsky's (1994) rankings of trade fair cities dropped from $1^{\text {st }}$ in the U.S. in 1964 to $3^{\text {rd }}$ in 1990, and it has since fallen to $5^{\text {th }}$ (TSW and CEIR, 2005). This is, in part, due to the growth of other trade fair cities and increasing competition between trade fair cities, a process also seen in Europe (Rinallo and Golfetto, 2011). Undoubtedly, Chicago's standing in the North American trade fair economy would have likely fallen even further if it had not expanded and modernized its trade fair center to compete with newer facilities elsewhere (Holten and Draeger, 1991).

Chicago is an example of a traditional center of industrial showcasing originally linked to its strong manufacturing base. It hosts large-scale national and international B2B fairs that induce important knowledge flows. Due to the transformation of the Manufacturing Belt and the rise of new trade fair centers elsewhere in the U.S., it has lost 
some of its former significance - although it is still an important trade fair center today. Chicago's experience illustrates the challenges that many Midwestern cities face in maintaining their place as key nodes in the global trade fair economy.

\section{Las Vegas: From Leisure Capital to Trade Fair Leader}

Las Vegas is almost synonymous with the North American trade fair industry today. It hosts one-third more trade fairs than its nearest competitor, including six out of the ten largest trade fairs in North America (Fenich and Hashimoto, 2004). The city's infrastructure is made up of trade fair venues in many of the the large hotel/casino complexes and the Las Vegas Convention Center (LVCC), a large exhibition hall established in 1959 by the Las Vegas Convention and Visitors Authority (LVCVA) - a public organization funded through a hotel room tax (LVCVA, 2011).

The city's excellent trade fair infrastructure is marked by its huge capacity and resources (Velotta, 1999; Jones, 2006). Las Vegas has more than 140,000 hotel rooms and over 43 million square feet of exhibition space (LVCVA, 2009). The LVCC is not only the third largest trade fair center in North America with almost 2 million square feet exhibition space (AUMA, 2009a), it also has the largest amount of surface parking of any center. This gives it the capacity to host trade fairs that no other city in North America can. World of Concrete, for instance, is an annual trade fair for the masonry and construction industries and one of the largest trade fairs in the world. It can only exhibit in the LVCC due to the large surface parking space it requires for demonstrations of cranes and other construction equipment and sufficient hotel capacity to house the more than 80,000 attendees. 
Originally, trade fairs were seen as a way to increase casino revenue by funneling business visitors into the city's gambling halls (Bergen, 2003; Fenich and Hashimoto, 2004). This was at a time when participation in trade fairs was sometimes regarded as a reward for successful employees rather than a critical business function (Tanner, 2002). Other cities, like Orlando and New Orleans, have also pursued this strategy with success. Their cultural and leisure activities help attract participants to not only attend the trade fair, but also to engage in the broader tourism economy.

According to LVCVA information (Interview with LVCVA official, March 2009), Las Vegas' business tourism likely began in earnest in 1959 with the establishment of the LVCVA, whose express purpose was to build the LVCC and promote trade fair and convention tourism. ${ }^{14}$ Until the early 1990 s, the LVCC was the city's dominant trade fair space. With the opening of the MGM Grand in 1993, the first hotel/casino to include substantial exhibition space, the LVCC began to compete with the local casinos for trade fairs (Interview with LVCVA official, March 2009). Since then, multiple hotels/casinos have been built with extensive exhibition space, such as the Sands Expo and Convention Center and the Mandalay Bay Convention Center (Yang, 2008; AUMA, 2009a).

Las Vegas' trade fair industry is unique in North America because of the simultaneous cooperation and competition between the public LVCVA and the privately run exhibition halls of the major hotels/casinos. The LVCVA is the main body responsible for promoting the city as both a tourist and trade fair destination. Its work in selling and branding Las Vegas as a trade fair destination (such as the famous slogan "What happens in Vegas, stays in Vegas") supports the city's hospitality industry. But the LVCVA also operates the LVCC, putting it in direct competition with the large hotels/casinos for trade fairs and exhibitions. While many other cities have a quasi- 
publicly operated trade fair center, no other city in North America has a similarly large concentration of major privately-run trade fair/exhibition centers. As a consequence of these influences, the city hosts a large number of major national and international trade fairs and specializes in large-scale and B2B events.

\section{Toronto: From Agricultural Market Place to Trade Fair Center}

Toronto is a more recent addition to the list of top North American trade fair cities. Similar to other Canadian and U.S. cities, it experienced a traditional path in the development of its trade fair infrastructure, starting out as a temporary regional market in the area of agriculture and manufacturing dating back to the 19th century with events like the Canadian National Exhibition and the Royal Agricultural Winter Fair (Osborne, 1980; Walden, 1997). The transformation into a modern trade fair city did not take place until the late 1970s to early 1980s. The Metro Toronto Convention Centre (MTCC) - the city's major downtown trade fair facility with about 460,000 square feet exhibition space plus an additional 180,000 square feet of meeting space - was created in 1984 as a partnership between the city, province, and federal government to boost tourism. Though funded as a partnership between all three levels of government, it is owned and managed by a provincial crown corporation (MTCC, 2011). The MTCC is particularly oriented towards scientific and medical conferences. Organizers see this as a way to tie into the city's strengths in biotechnological and medical research both at local universities and firms. ${ }^{15}$ In addition, the City of Toronto owns and operates the Direct Energy Centre - a trade fair facility that opened in 1996 (renamed in 2006) on the exhibition grounds a few kilometers west of the MTCC. With 1.1 million square feet of exhibition space, the Direct Energy Centre is the largest such facility in Canada, substantially larger than the MTCC 
(Direct Energy Centre, 2010). Due to its three large interconnected exhibition halls and its tradition, this facility was primarily used for larger B2C fairs. In recent years, the facilities were expanded and transformed to become more oriented towards B2B fairs, as well as conventions and meetings (Interview with Direct Energy Center officials, December 2009).

Toronto is unusual in that it has two publicly owned convention centers. While there is competition between the MTCC and the Direct Energy Centre, each has a different focus. The Direct Energy Centre has larger exhibit halls than the MTCC, making it a better venue for consumer-oriented shows, while the MTCC has a large number of smaller meeting rooms for conferences and trade fairs with a strong educational or instructional component. Thus, the two facilities seldom compete directly for an event. Rather, they compete against other cities to attract particular events (Interviews with MTCC officials, July 2009 and with Direct Energy Centre officials, December 2009). Moreover, Toronto has two privately-run exhibition halls. The International Centre (International Centre, 2011) and Toronto Congress Centre were built in 1972 and 1995, respectively (Toronto Congress Centre, 2011). Both are located close to Pearson International Airport, about 30 kilometers west of downtown Toronto. As these facilities are smaller than their publicly-financed counterparts (together still over 1 million square feet), they focus more on local and regional trade fairs compared to larger, more nationally- and internationally-oriented events in the downtown venues.

Overall, the trade fair business in Toronto tends not to be strongly linked to the regional industry base, although its events do have a substantial proportion of regional exhibitors and visitors. Toronto's trade fair economy is marked by competition between the two public conference centers close to the downtown core and the two privately-run 
centers in the suburbs. A similar structure of core-periphery competition can also be found in other North American trade fair cities; Atlanta is a good example (Newman, 2002).

The suburban exhibition halls - adding substantial exhibition space - contribute to Toronto's high number of consumer-oriented fairs. While these are primarily regional, they are viewed as an important way to advertise the trade fair facilities and to generate interest in future events (Interview with MTCC officials, July 2009). Such consumer fairs are less important to the wider regional economy, since fewer people come from outside the city traveling over a longer distances and do not consume as many local services (yet they still generate sizable revenues for the trade fair center).

\section{Conclusions: Dynamic Trade Fair Geographies}

Global buzz at trade fairs enables firms to systematically acquire knowledge about competitors, suppliers, and customers, as well as undertake first steps toward the development of durable inter-firm knowledge pipelines in research, production, and/or marketing (Bathelt and Schuldt, 2008). These pipelines are critical to help firms monitor new developments and trends within their industry. In this sense, trade fairs are key relational events in the global economy. But trade fairs also materialize in place and produce substantial regional support economies. They generate jobs and incomes, particularly in the urban centers that host them. A core idea of a relational approach in economic geography should be that these two perspectives - i.e., of a more durable material-based and a more ephemeral relationship-based spatial economy - are not independent from one another. Material and non-material geographies are bound together in reflexive processes as historical structures, investment decisions, and urban 
development strategies, which induce particular patterns of knowledge flows and communication during local trade fairs, which, in turn, impact the regional economy and lead to further investments. In this vein, this article focuses on the material aspects of North American trade fair geographies, the different structures that have emerged, and their dynamic development.

This research provides evidence of the continued growth of North American trade fairs despite changes in the capitalist system and various crises that have occurred over the past decade. We can witness a shift from traditional manufacturing cities to new trade fair locations in the West and South of the U.S., the rise of Canadian cities as important trade fair locations, the continued importance of large international metropolitan regions, as well as the impact of local and regional policies on the trade fair business through investments into new or modernized world-scale facilities. In terms of the latter form of investment, Las Vegas was a first mover in North America's growing trade fair economy, but other cities soon followed. Major industrial cities, like New York, Chicago, Boston, and Detroit, also began extending and modernizing exhibition halls later on. These are the cities that dominated Zelinsky's (1994) account of the trade fair economy during the 1960s. A second major wave of construction began in the late 1970s, often as part of an urban revitalization campaign designed to attract jobs and tourists to the declining downtown areas of major cities. Examples include the Baltimore Convention Center, which opened in 1979 and became the linchpin of Baltimore's Inner Harbor renovations, or the David L. Lawrence Convention Center in Pittsburgh that opened in 1981 as part of a larger urban renewal project. Other cities, which developed their trade fair infrastructure in the mid 1990s, like Hartford, Connecticut, and Columbus, Ohio, do not yet appear among the top 25 trade fair cities, but have certainly gained in importance. 
While the latter cities have new state-of-the-art facilities, they are still somewhat peripheral in the urban hierarchy and not well integrated into international transportation systems.

If future shifts in the geography of trade fairs are driven by a high degree of competition between cities and by a need to gain accessibility and visibility in relation to global markets (Rinallo and Golfetto, 2011), the leading metropolitan areas and transportations hubs with large international airports will likely become even more dominant as trade fair centers in the future. Following this line of argument, we would expect that these centers will attract trade fairs from other cities, thus moving up in the hierarchy of trade fair places. This would also strengthen their position at the top of the urban hierarchy, while smaller and more remote cities would fall behind.

According to a report by RolandBerger (2009), such trends are supported by increasing concentration in the trade fair industry. Since 2005, the market share of the top 20 trade show organizers increased by $12 \%$ to include over half of the global market. This trend is also apparent in North America (AUMA, 2009a). Driven by the 2008 global financial crisis, we might expect a number of trends to influence the development of global trade fair geographies in the future. These include further concentration in the industry, relocations to new growth centers in Asia, experimentation with new trade fair formats in niche markets, as well as merger activities in established market segments. In Germany, for instance, the two major flagship fairs Collectione and Tendence Lifestyle were combined in 2007. Such mergers create even larger shows that can attract an international audience and become key sites for knowledge exchange and circulation. However, they can only be held in cities with substantial trade fair infrastructure and international air connections. While trade fair business will eventually recover from the 
decline due to the global financial crisis, industry shifts will make it harder for secondtier cities in North America to become or remain important international trade fair centers in the future, requiring them to either significantly expand the size of their infrastructure or target a reduced market for more local shows.

\section{$\underline{\text { Acknowledgements }}$}

This paper was prepared for the 2010 annual meeting of the Association of American Geographers in Washington, DC. We wish to thank three anonymous reviewers for helpful comments and Ian MacLachlan for thorough and constructive guidance. The authors, who contributed equally to the manuscript, would also like to thank Rachael Gibson, Nina Schuldt, and Phil Turi for their research support, and Susan Christopherson, Dieter Kogler, and Elmar Kulke for encouraging feedback. The usual disclaimers apply. Financial support by the Canadian Social Sciences and Humanities Research Council is greatly appreciated.

\section{References}

Allix, A. 1922. The geography of fairs: Illustrated by old-world examples. Geographical Review, 12: 532-569.

AUMA - Ausstellungs- und Messeausschuss der deutschen Wirtschaft 2002.

Messemärkte Ausland - Kanada (Foreign Trade Fair Markets - Canada). Berlin: AUMA.

http://www.auma.de/_pages/d/04_MessemaerkteAusland/0402_Laenderprofile/04 $\underline{0215 \text { Kanada/04021501_Uebersicht.aspx. }}$.

_ 2004a. Messemarkt USA (Trade Fair Market USA). AUMA_Compact Nr. 5, March 10. Berlin: AUMA. 
2004b. Messemarkt Mexiko (Trade Fair Market Mexico). Berlin: AUMA.

http://www.auma.de/_pages/d/04_MessemaerkteAusland/0402_Laenderprofile/04

0218_Mexiko/download/MessemarktMexiko.pdf.

_2009a. Messemarkt USA (Trade Fair Market USA). Berlin: AUMA.

http://www.auma.de/_pages/d/04_MessemaerkteAusland/0402_Laenderprofile/04

0226_USA/download/Messemarkt_USA.pdf.

_ 2009b. Die Messewirtschaft: Bilanz 2008 (The Trade Fair Economy: 2008 Balance). Berlin: AUMA.

_2009c. Die gesamtwirtschaftliche Bedeutung von Messen und Ausstellungen in Deutschland: Ergebnisse für ein durchschnittliches Messejahr des Zeitraums 2005-2008 (Annual Economic Effects of Trade Fairs and Exhibitions in Germany: Average of the Years 2005-2008). Berlin: AUMA.

Backhaus, H. and Zydorek, C. 1997. Von der Mustermesse zur ubiquitären Messe (From sample fairs to ubiquitous trade fairs). In: Märkte im Dialog: Die Messen der dritten Generation (Markets in Dialogue: Trade Fairs of the Third Generation), eds H. Meffert, T. Necker. and H. Sihler. Wiesbaden: Gabler, 134-158.

Bathelt, H. 2006. Geographies of production: Growth regimes in spatial perspective 3 Toward a relational view of economic action and policy. Progress in Human Geography, 38: 223-236, doi: 10.1191/0309132506ph603pr.

2011. International trade fairs and world cities: Temporary vs. permanent clusters. In: International Handbook of Globalization and World Cities, eds. P. Taylor, B. Derudder, M. Hoyler, and F. Witlox. Cheltenham and Northampton, MA: Edward Elgar. 
Bathelt, H. and Glückler, J. 2011. The Relational Economy: Geographies of Knowing and Learning. Oxford: Oxford University Press.

Bathelt, H. and Schuldt, N. 2008. Between luminaries and meat grinders: International trade fairs as temporary clusters. Regional Studies, 42(6): 853-68, doi: $10.1080 / 00343400701543298$

Bathelt, H. and Schuldt, N. 2010. International trade fairs and global buzz, Part I: Ecology of Global Buzz. European Planning Studies, 18(12): 1957-1974, doi: $10.1080 / 09654313.2010 .515815$.

Bergen, K. 2003. Las Vegas and Orlando bruising Chicago's trade show business. Chicago Tribune, September 11.

Boggs, J. S. 2005. The Geographical Sources of Competitive Advantage and Specialization in the Book Trade of Frankfurt-am-Main and Berlin. Doctoral dissertation, University of California, Los Angeles.

Borghini, S., Golfetto, F. and Rinallo, D. 2004. Using Anthropological Methods to Study Industrial Marketing and Purchasing: An Exploration of Professional Trade Shows. Paper presented at the Industrial Marketing Purchasing Conference, Copenhagen.

_ 2006. Ongoing search among industrial buyers. Journal of Business Research, 59(10-11): 1151-1159, doi: 10.1016/j.jbusres.2006.06.005.

Bradley, A., Hall, T., and Harrison, M. 2002. Selling cities: Promoting new images for meetings tourism. Cities, 19(1): 61-70, doi: 10.1016/S0264-2751(01)00046-4.

Breiter, D. and Hahm, J. 2006. International Participation at Association Meetings and Conventions Report. Report to the National Convention Management Association - Industry Issues Committee, Chicago. 
CEIR - Center for Exhibition Industry Research. 2005. 2nd Annual CEIR Index: 2005 Edition. Chicago: CEIR.

_ 2009. CEIR Index Events: 2001 - 2007 Aggregate Totals. Unpublished data provided from the CEIR. Chicago: CEIR.

CERMES - Research Centre on Markets and Industrial Sectors. 2005. Trade Fair Observatory - International Trade Fair Report on Leading 5 European Countries (2005): Statistical Appendix. Milano: Bocconi University - CERMES.

Diez, J. R. and Kramer, J. 2000. EXPO 2000 - eine ökonomische Bilanz für die Region Hannover (Economic impact of the EXPO 2000 in Hanover). Geographische Rundschau, 52(5): 25-31.

Direct Energy Centre. 2010. About Direct Energy Centre. Toronto.

http://www.directenergycentre.com/database/rte/files/AboutDirect $\% 20$ Energy $\% 2$ 0Centre.pdf.

Entwistle, J. and Rocamora, A. 2006. The field of fashion materialized: A study of London Fashion Week. Sociology, 40: 735-751, doi: 10.1177/0038038506065158.

Fenich, G. G. and Hashimoto, K. 2004. Casinos and conventions: Strange bedfellows. In Current Issues in Convention and Exhibition Facility Development: ed R. R. Nelson. Binghamton, NY: Haworth Hospitality, pp. 63-80.

Findling, J. E. and Pelle, K. D. 2008. Encyclopedia of World's Fairs and Expositions. Jefferson, NC: McFarland \& Co.

Fuchslocher, H. and Hochheimer, H. 2000. Messen im Wandel: Messemarketing im 21. Jahrhundert (Trade Fair Marketing in the 21st Century). Wiesbaden: Gabler. 
Godar, S. and O'Connor, P. 2001. Same time next year - Buyer trade show motives. Industrial Marketing Management, 30(1): 77-86, doi: 10.1016/S00198501(99)00100-5.

High Point Market. 2010. About High Point Market. High Pint, NC. http://www.highpointmarket.org/AboutMarket.aspx.

Holten, L. and Draeger, H. 1991. Is the city losing its convention pull? Bustling, lucrative trade show business at a crossroads. Chicago Sun-Times, June 2.

International Centre. 2011. International Centre: History. Toronto. http://www.internationalcentre.com/history.

Jones, C. 2006. Trade shows big and growing. Las Vegas Review-Journal, April 26.

Kaiser, C. 2002. Die Welt zu Gast in Hannover: Eine Bilanz der ersten deutschen Weltausstellung EXPO 2000 (The world visiting Hanover: Outcomes from the world exhibition EXPO 2000). Berichte zur deutschen Landeskunde, 76: 31-52.

Kijewski, V., Yoon, E., and Young, G. 1993. How exhibitors select trade shows. Industrial Marketing Management, 22(4): 287-298.

Kresse, H. 2003. The European Trade Fair Industry: Current Situation and Challenges. Mimeo. Berlin: AUMA.

Law, C. 1987. Conference and exhibition tourism. Built Environment, 13(2): 85-95.

LVCVA - Las Vegas Convention and Visitors Authority. 2009. 2009 Las Vegas YearTo-Date Executive Summary. Las Vegas. http://www.lvcva.com/getfile/ESYTD2009.pdf?fileID=479.

— 2011. About the LVCVA. Las Vegas. http://www.lvcva.com/about/index.jsp. 
Lee, M. and Back, J. 2005. A review of economic value drivers in convention and meeting management research. International Journal of Contemporary Hospitality Management, 17(5): 409-420, doi: 10.1108/09596110510604832.

Malecki, E. and Poehling, R. 1999. Extroverts and introverts: Small manufacturers and their information sources. Entrepreneurship and Regional Development, 11(3): 247-268.

Maskell, P., Bathelt, H. and Malmberg, A. 2004. Temporary clusters and knowledge creation: The effects of international trade fairs, conventions and other professional gatherings. SPACES (2004-04). Toronto, Heidelberg: www.spacesonline.com.

_2006. Building global knowledge pipelines: The role of temporary clusters. European Planning Studies, 14(8): 997-1013, doi: 10.1080/09654310600852332.

McKim, W. 1972. The periodic market system in Northeastern Ghana. Economic Geography, 48(32): 333-344.

Metropolitan Pier and Exposition Authority. 2011. McCormick Place: About us. Chicago. http://www.mccormickplace.com/about_us/about_us.html.

MTCC - Metropolitan Toronto Convention Centre. 2011. MTCC Corporate Objective and Mandate. Toronto. http://www.mtccc.com/.

Moellenberg, A. and Teichmann, O. 2000. Die virtuelle Messe als Marketinginstrument: Bestandsaufnahme und Zukunftsperspektiven (The virtual trade fairs as a marketing instrument). Arbeitspapier AP-Nr. 00/04. Braunschweig: University of Braunschweig. http://www.wiwi.tu-bs.de/marketing/publikationen/ap/ap_liste.htm. Newman, H. 2002. Decentralization of Atlanta's convention business. Urban Affairs Review, 38(2): 232-252, doi: 10.1177/107808702762484105. 
Norcliffe, G. and O. Rendace 2003. The new geographies of comic book production in North America: The artisan, distancing, and the periodic social economy. Economic Geography, 79(3): 241-263, doi: 10.1111/j.1944-8287.2003.tb00211.x

Oppermann, M. 1996. Convention destination images: Analysis of association meeting planners’ perceptions. Tourism Management, 17(3): 175-182, doi:10.1016/02615177(96)00004-0.

Oppermann, M. and Chon, K.-S. 1997. Convention participation decision-making process. Annals of Tourism Research, 24(1): 178-191, doi: 10.1016/S01607383(96)00049-7.

Osborne, B. (1980). Trading on a frontier: The function of peddlers, markets, and fairs in nineteenth-century Ontario. In: Canadian Papers in Rural History, 2, ed. D. H. Akenson. Gananoque, ON: Langdale, pp. 59-81.

Penaloza, L. 2001. Consuming the American West: Animating cultural meaning and memory at a stock show and rodeo. Journal of Consumer Research, 28: 369-398, doi: $10.1086 / 323728$.

Penzkofer, H. 2008. Messen und Veranstaltungen der Messe München lösen bundesweit jährlich einen Umsatz von 2,17 Mrd. Euro aus (Trade fairs and related events in Munich generate annual sales effects of Euro 2.17 billion in Germany). ifo Schnelldienst, 61(10): 38-43.

Perry, D. C. and Watkins, A. J. 1977. The Rise of the Sunbelt Cities. Beverly Hills and London: Sage.

Piore, M. J. and Sabel, C. F. 1984. The Second Industrial Divide: Possibilities for Prosperity. New York: Basic Books. 
Power, D. and Jansson, J. 2008. Cyclical clusters in global circuits: Overlapping spaces in furniture trade fairs. Economic Geography, 84(4): 423-448, doi: 10.1111/j.19448287.2008.00003.x.

Prüser, S. M. 2003. Die Messe als Networking-Plattform (Trade fairs as a platform for networking). In: Handbuch Messemanagement: Planung, Durchführung und Kontrolle von Messen, Kongressen und Events (Handbook of Trade Fair Management: Planning, Execution and Control of Trade Fairs, Conventions and Events), eds M. Kirchgeorg W. M. Dornscheidt, M., W. Giese and N. Stoeck: Wiesbaden: Gabler, pp. 1181-1195.

Rallet, A. and Torre, A. 2009. Temporary geographical proximity for business and work coordination: When, how and where? SPACES (2009-02). Toronto, Heidelberg: www.spaces-online.com.

Ramirez-Pasillas, M. 2008. Resituating proximity and knowledge: Cross-fertilization in clusters by means of international trade fairs. European Planning Studies, 16(5): 643-663, doi: 10.1080/09654310802049158.

Rinallo, D. and Golfetto, F. 2011. Exploring the knowledge strategies of temporary cluster organizers: A longitudinal study of the EU fabric industry trade shows (1986-2006). Economic Geography, 87: forthcoming, doi: 10.1111/j.19448287.2011.01127.x.

Rodekamp, V. 2003. Zur Geschichte der Messen in Deutschland und Europa (On the history of trade fairs in Germany and Europe). In: Handbuch Messemanagement: Planung, Durchführung und Kontrolle von Messen, Kongressen und Events (Handbook of Trade Fair Management: Planning, Execution and Control of 
Trade Fairs, Conventions and Events), eds. M. Kirchgeorg., W. M Dornscheidt, W. Giese and N. Stoeck. Wiesbaden: Gabler, pp. 5-13.

RolandBerger. 2009. Getting ready for the future after the crisis. Discussion Paper, RolandBerger Strategy Consultants: Munich.

Rosson, P. J. and Seringhaus, F. H. R. 1995. Visitor and exhibitor interaction at industrial trade fairs. Journal of Business Research, 32(1): 81-90, doi: 10.1016/01482963(94)00012-4.

Sanders, H. 1992. Building the convention city: Politics, finance and public investment in urban America. Journal of Urban Affairs, 14(2): 135-159, doi: 10.1111/j.14679906.1992.tb00282.x.

Sanders, H. 2002. Convention myths and markets: A critical review of convention center feasibility studies. Economic Development Quarterly, 16(2): 195-210, doi: $10.1177 / 08942402016003001$.

Schätzl, L., Kramer, J. and Sternberg, R. 1993. Regionalökonomische Wirkungen der 1991 in Hannover veranstalteten Messen und Ausstellungen (Regional economic impact of the 1991 trade fairs and exhibitions in Hanover). In: Polit-Marketing auf Messen (Marketing Policy on Trade Fairs) ed.K. E. Goehrmann.. Düsseldorf: Verlag Wirtschaft und Finanzen, pp. 98-112.

Sharland, A. and Balogh, P. 1996. The value of nonselling activities at international trade shows. Industrial Marketing Management, 25(1): 59-66, doi: 10.1016/00198501(95)00065-8.

Spillman, B. 2007. LV still a great place to show: City tops list of best convention places. Las Vegas Review-Journal, May 1. 
Tanner, J. J. 2002. Leveling the playing field: Factors influencing trade show success for small companies. Industrial Marketing Management, 31(3): 229-239, doi: 10.1016/S0019-8501(00)00132-2.

Toronto Congress Center. 2011. The Toronto Congress Centre: Our History. Toronto. http://www.torontocongresscentre.com/attending/our-history.htm.

Tourism Vancouver 2007. Economic Impact of Meetings and Conventions in Metro Vancouver, 2000-2007. Vancouver. http://www.tourismvancouver.com/pdf/research/mc economic impact.pdf.

TSW - Trade Show Week and CEIR 2005. Exhibition Industry Census II: Comprehensive Resource of Exhibition Industry Data. Chicago.

Udosen, C. and Adams, D. 2009. A spatio-temporal synchronization of periodic markets: Evidence from the hinterland of Akwa Ibom State. Global Journal of Social Sciences, 8(1): 27-37.

Velotta, R. V. 1999. Convention center expansion touted as competitive tool. Las Vegas Sun, January 5.

Velotta, R. V. 2009. Trade shows bringing mobs to Vegas when it needs it most: Consumer Electronics Show, which could draw 130,000, starts next week. Las Vegas Sun, January 5.

Walden, K. 1997. Becoming Modern in Toronto: The Industrial Exhibition and the Shaping of Late Victorian Culture. Toronto: University of Toronto Press.

Wilkinson, T. and Brouthers, L. 2006. Trade promotion and SME export performance. International Business Review, 15(3): 233-252, doi:

10.1016/j.ibusrev.2006.03.001.

Yang, C. 2008. A look at Las Vegas: At the top of the heap. Tradeshow Week, May 12. 
Yeung, H. W. 2005: Rethinking relational economic geography. Transactions of the Institute of British Geographers, NS 30(1): 37-51, doi: 10.1111/j.14755661.2005.00150.x.

Zelinsky, W. 1994. Conventionland USA: The geography of a latterday phenomenon. Annals of the Association of American Geographers, 84(1): 68-86, doi: 10.1111/j.1467-8306.1994.tb01729.x. 

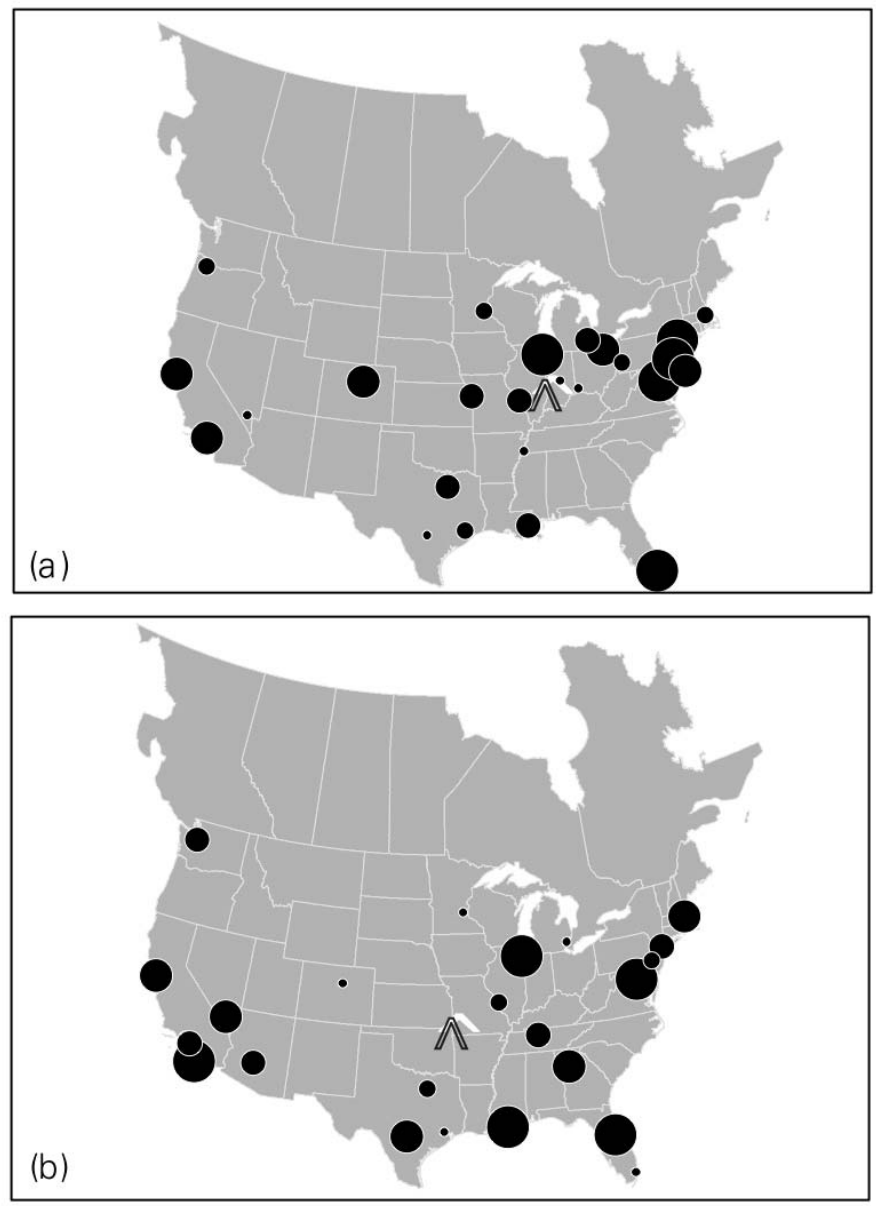

Rank Order of Trade Fair Cities by Number of Shows

1-5

6-10

- $11-15$

- $16-20$

- $21-25$

$\mathbb{A}$ Mean Center of TradeFair Activity

(c)

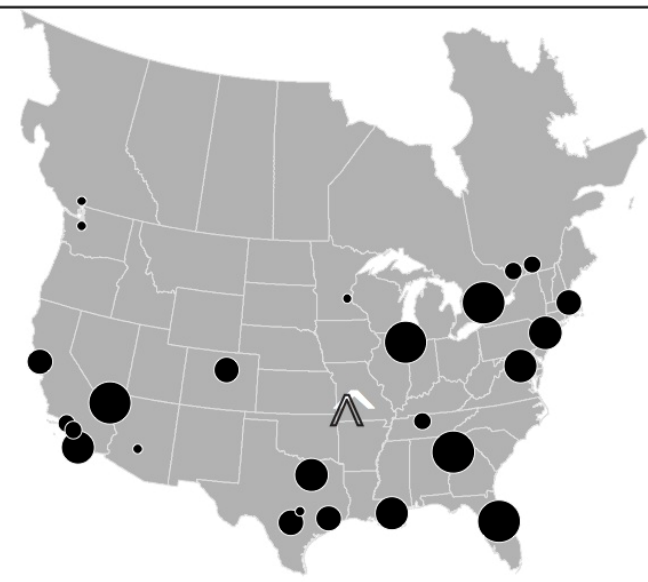

Figure 1: Top 25 North American Trade Fair Cities by Rank (a) 1964, (b) 1990, and (c) 2005 (Source: Zelinsky, 1995; CEIR, 2005) 
Number of Trade Fairs - Average Size of Trade Fairs

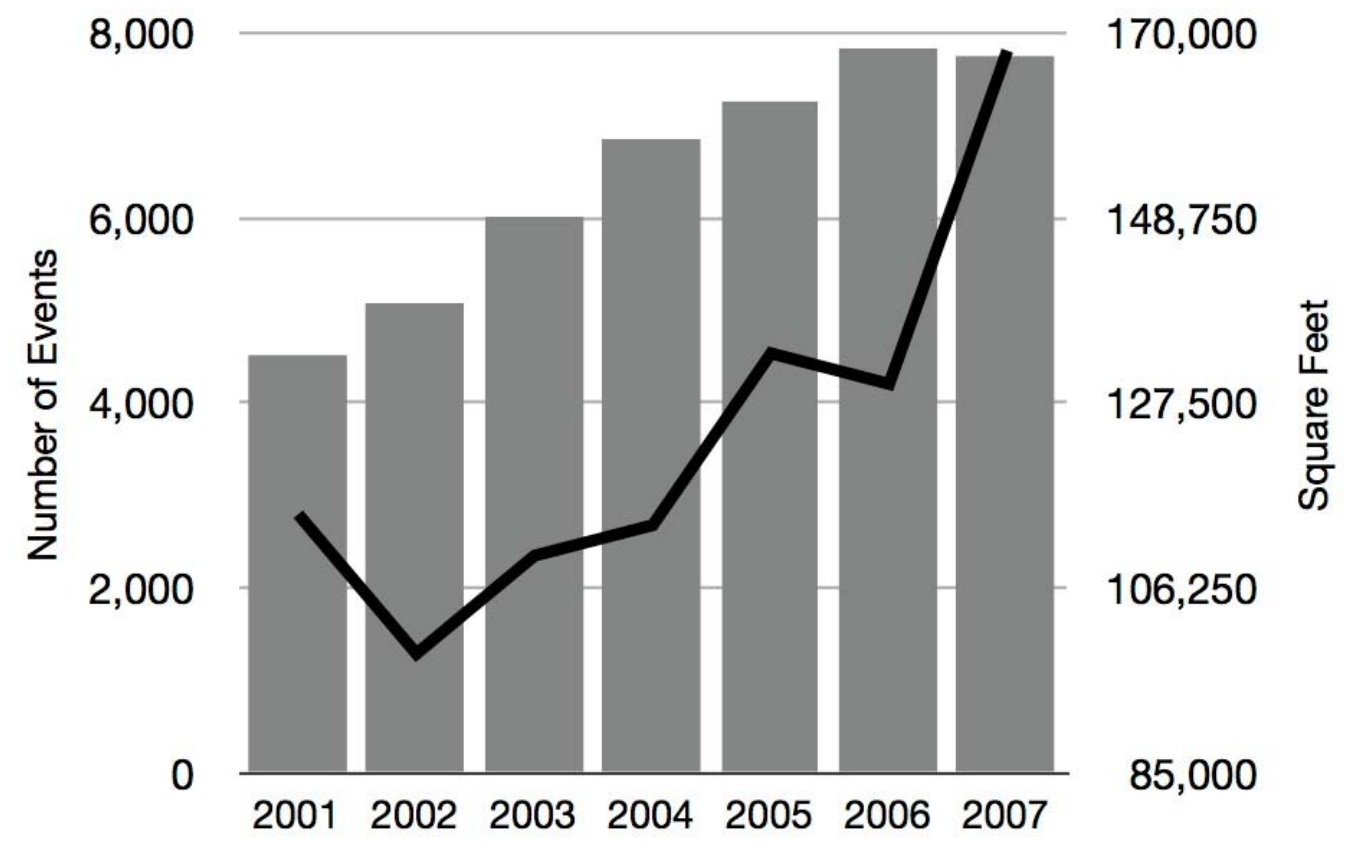

Figure 2: Total Number and Average Square Footage of North American Trade Fairs, 2001-2007 (Source: CEIR, 2005; 2007) 


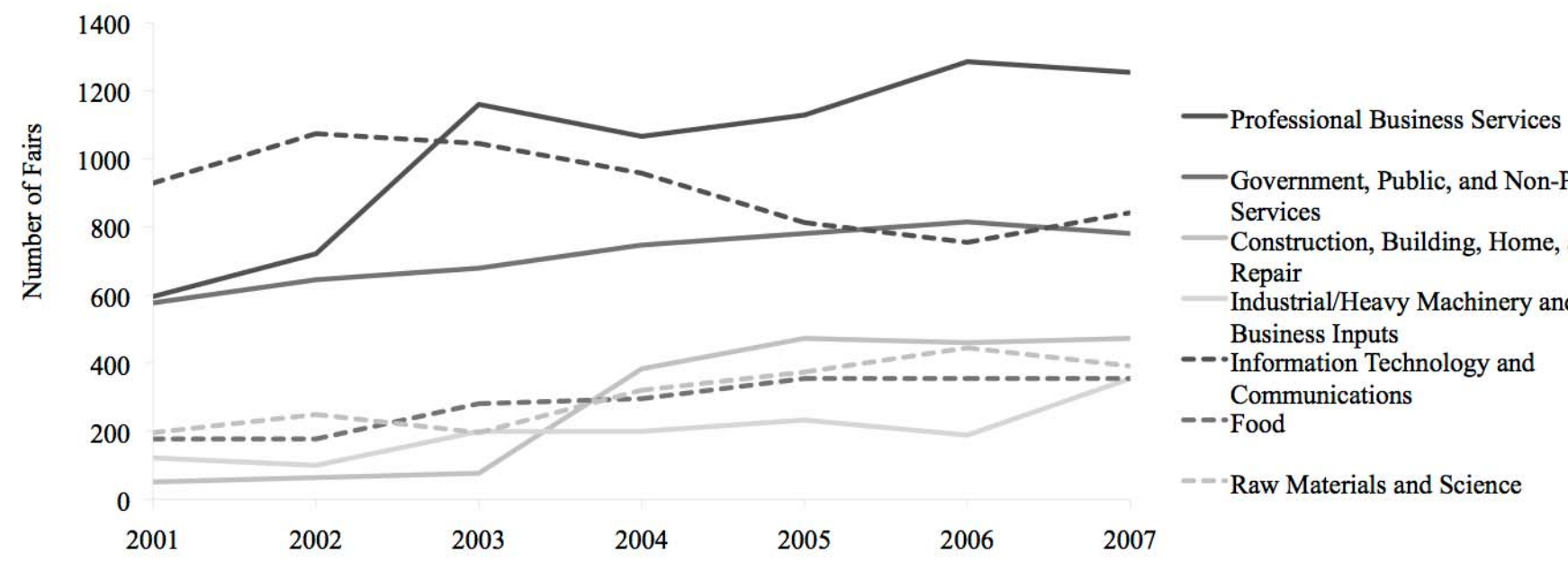

(a)

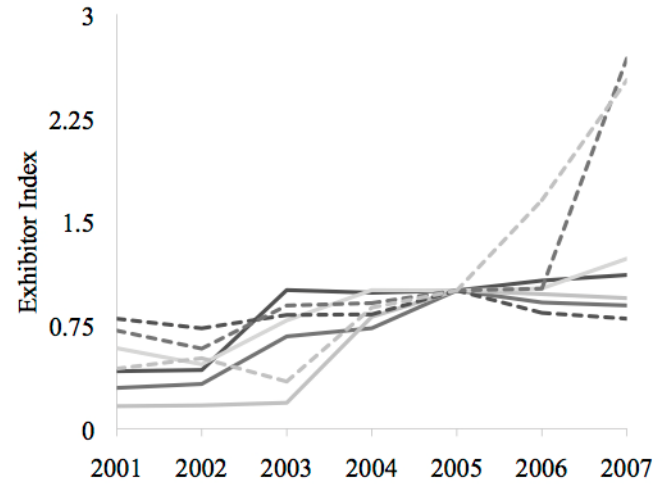

(b)

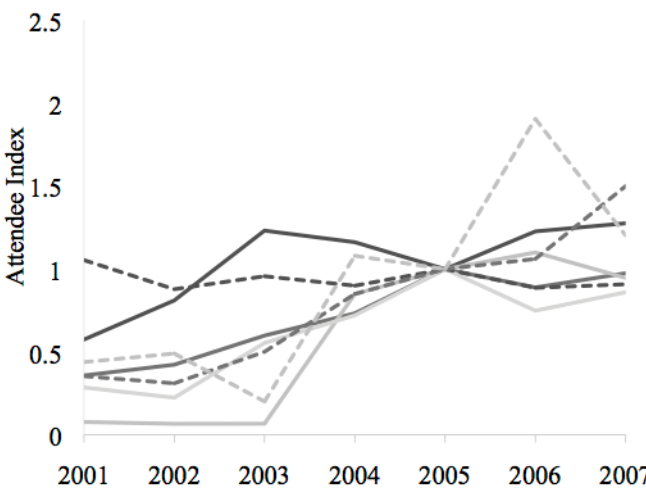

(c)

Figure 3: (a) Number of Trade Fairs, (b) Index of Trade Fair Exhibitors (2005=1.0), and (c) Index of Trade Fair Attendees $(2005=1.0)$ in the Top 25 North American Trade Fair Cities by Selected Industrial Sectors, 2001-2007 (Source: CEIR, 2005; 2009) 
Table 1: Average Number of Exhibitors, Attendees, and Square Footage of North American Trade Fairs, 2001, 2004 , and 2007 (Source: CEIR, 2005; 2007)

\begin{tabular}{|c|c|c|c|c|c|c|c|c|c|}
\hline \multirow[t]{2}{*}{ Industrial Sector } & \multicolumn{3}{|c|}{ Exhibitors per Event } & \multicolumn{3}{|c|}{ Attendees per Event } & \multicolumn{3}{|c|}{$\begin{array}{l}\text { Average Size of Event } \\
\text { (Square Feet) }\end{array}$} \\
\hline & 2001 & 2004 & 2007 & 2001 & 2004 & 2007 & 2001 & 2004 & 2007 \\
\hline $\begin{array}{l}\text { Professional Business } \\
\text { Services (BZ) }\end{array}$ & 308 & 408 & 461 & 5,623 & 6,350 & 6,586 & 61,324 & 81,761 & 104,670 \\
\hline Consumer Goods and & & & & & & & & & \\
\hline $\begin{array}{l}\text { Retail Trade (CG) } \\
\text { Consumer Services, Sports, }\end{array}$ & 776 & 706 & 720 & 16,156 & 14,502 & 15,210 & 220,531 & 177,117 & 355,082 \\
\hline $\begin{array}{l}\text { Travel, Entertainment, and } \\
\text { Art (CS) }\end{array}$ & 397 & 438 & 520 & 9,726 & 11,402 & 16,171 & 123, & 131,705 & 180.620 \\
\hline Food (FD) & 520 & 399 & 981 & 8,965 & 12,924 & 19,010 & 174,853 & 104,759 & 150,568 \\
\hline Government, Public, and & & & & & & & & & \\
\hline $\begin{array}{l}\text { Non-Profit Services (GV) } \\
\text { Construction, Building, }\end{array}$ & 113 & 216 & 265 & 2,700 & 3,767 & 5,009 & 15,847 & 39,428 & 55,402 \\
\hline $\begin{array}{l}\text { Home, and Repair (HM) } \\
\text { Industrial/Heavy }\end{array}$ & 563 & 374 & 369 & 18,665 & 27,169 & 25,970 & 246,055 & 116,368 & 107,642 \\
\hline $\begin{array}{l}\text { Machinery and Finished } \\
\text { Business Inputs (ID) }\end{array}$ & 639 & 712 & 495 & 7,837 & 12,069 & 8,098 & 125,393 & 176,935 & 165,002 \\
\hline Information Technology & & & & & & & & & \\
\hline $\begin{array}{l}\text { and Communications (IT) } \\
\text { Medical and Health Care }\end{array}$ & 189 & 178 & 226 & 6,353 & 5,259 & 6,489 & 61,828 & 54,308 & 66,606 \\
\hline (MD) & 197 & 219 & 242 & 4,776 & 4,828 & 5,364 & 65,987 & 73,380 & 78,319 \\
\hline $\begin{array}{l}\text { Raw Materials and science } \\
(\mathrm{RM})\end{array}$ & 267 & 329 & 898 & 7,254 & 10,909 & 11,510 & 65,062 & 116,139 & 220,209 \\
\hline Transportation (TX) & 199 & 234 & 249 & 20,714 & 20,173 & 16,229 & 89,239 & 120,176 & 104,696 \\
\hline Unweighted Average & 379 & 383 & 494 & 9,888 & 11,759 & 12,331 & 114,755 & 113,509 & 167,980 \\
\hline
\end{tabular}

Source: CEIR, 2005; 2007 
Table 2: Top 25 North American Trade Fair Cities by Business Focus, 2005 (Source: CEIR, 2005)

\begin{tabular}{|c|c|c|c|c|c|c|}
\hline \multirow{3}{*}{$\begin{array}{l}\text { Rank } \\
1\end{array}$} & \multirow{3}{*}{$\begin{array}{l}\text { City } \\
\text { Las Vegas, NV }\end{array}$} & \multicolumn{5}{|c|}{$\begin{array}{l}\text { Number and Share of Trade Fairs } \\
\text { by Business Focus }\end{array}$} \\
\hline & & \multirow{2}{*}{$\begin{array}{l}\text { Total } \\
780\end{array}$} & \multicolumn{2}{|c|}{$\begin{array}{l}\text { Business-to- } \\
\text { Business (B2B) }\end{array}$} & \multicolumn{2}{|c|}{$\begin{array}{l}\text { Business-to- } \\
\text { Consumer (B2C) }\end{array}$} \\
\hline & & & 718 & $92 \%$ & 62 & $8 \%$ \\
\hline 2 & Toronto, ON & 605 & 224 & $37 \%$ & 381 & $63 \%$ \\
\hline 3 & Orlando, FL & 582 & 547 & $94 \%$ & 35 & $6 \%$ \\
\hline 4 & Atlanta, GA & 478 & 387 & $81 \%$ & 91 & $19 \%$ \\
\hline 5 & Chicago, IL & 431 & 397 & $92 \%$ & 34 & $8 \%$ \\
\hline 6 & New York, NY & 419 & 373 & $89 \%$ & 46 & $11 \%$ \\
\hline 7 & Dallas, TX & 344 & 261 & $76 \%$ & 83 & $24 \%$ \\
\hline 8 & San Diego, CA & 338 & 314 & $93 \%$ & 24 & $7 \%$ \\
\hline 9 & New Orleans, LA & 333 & 313 & $94 \%$ & 20 & $6 \%$ \\
\hline 10 & Washington, DC & 294 & 273 & $93 \%$ & 21 & $7 \%$ \\
\hline 11 & Houston, TX & 229 & 165 & $72 \%$ & 64 & $28 \%$ \\
\hline 12 & San Antonio, TX & 226 & 199 & $88 \%$ & 27 & $12 \%$ \\
\hline 13 & Denver, CO & 222 & 164 & $74 \%$ & 58 & $26 \%$ \\
\hline 14 & San Francisco, CA & 222 & 206 & $93 \%$ & 16 & $7 \%$ \\
\hline 15 & Boston, MA & 210 & 176 & $84 \%$ & 34 & $16 \%$ \\
\hline 16 & Montreal, QC & 198 & 121 & $61 \%$ & 77 & $39 \%$ \\
\hline 17 & Anaheim, CA & 193 & 172 & $89 \%$ & 21 & $11 \%$ \\
\hline 18 & Nashville, TN & 189 & 170 & $90 \%$ & 19 & $10 \%$ \\
\hline 19 & Los Angeles, CA & 181 & 141 & $78 \%$ & 40 & $22 \%$ \\
\hline 20 & Ottawa, ON & 179 & 102 & $57 \%$ & 77 & $43 \%$ \\
\hline 21 & Vancouver, BC & 177 & 99 & $56 \%$ & 78 & $44 \%$ \\
\hline 22 & Austin, TX & 169 & 134 & $79 \%$ & 35 & $21 \%$ \\
\hline 23 & Seattle, WA & 152 & 120 & $79 \%$ & 32 & $21 \%$ \\
\hline 24 & Minneapolis, MN & 151 & 119 & $79 \%$ & 32 & $21 \%$ \\
\hline 25 & Phoenix, AZ & 135 & 115 & $85 \%$ & 20 & $15 \%$ \\
\hline Total & & 7437 & 6011 & $81 \%$ & 1426 & $19 \%$ \\
\hline
\end{tabular}

Source: CEIR, 2005 
Table 3: Number of Trade Fairs by Industrial Sector in Selected North American Trade Fair Cities, 2005 (Source: CEIR, 2005)

\begin{tabular}{|c|c|c|c|c|c|c|c|c|c|c|c|c|}
\hline \multirow[t]{2}{*}{ City } & \multicolumn{9}{|c|}{ Number of Trade Fairs by Industrial Sector } & \multirow[b]{2}{*}{$\mathrm{RM}$} & \multirow[b]{2}{*}{$\mathrm{TX}$} & \multirow[b]{2}{*}{ Total } \\
\hline & BZ & $\mathrm{CG}$ & $\mathrm{CS}$ & FD & $\mathrm{GV}$ & HM & ID & IT & MD & & & \\
\hline \multirow{2}{*}{ Las Vegas, NV } & 127 & 114 & 80 & 46 & 42 & 53 & 28 & 111 & 86 & 26 & 51 & 780 \\
\hline & & 1.3 & & 1.2 & & & & 1.3 & & & 1.7 & \\
\hline \multirow{2}{*}{ Toronto, $\mathrm{ON}$} & 80 & 92 & 132 & 36 & 42 & 38 & 16 & 48 & 60 & 28 & 21 & 605 \\
\hline & & 1.4 & & 1.2 & & & & & & & & \\
\hline \multirow{2}{*}{ Chicago, IL } & 75 & 25 & 37 & 25 & 45 & 20 & 21 & 58 & 81 & 19 & 12 & 431 \\
\hline & & & & 1.2 & & & 1.5 & 1.2 & 1.3 & & & \\
\hline \multirow{2}{*}{ Dallas, TX } & 54 & 66 & 40 & 17 & 24 & 32 & 10 & 22 & 32 & 10 & 20 & 344 \\
\hline & & 1.7 & & & & 1.5 & & & & & 1.6 & \\
\hline \multirow{2}{*}{ San Diego, CA } & 61 & 21 & 23 & 11 & 52 & 5 & 7 & 47 & 75 & 19 & 12 & 338 \\
\hline & & & & & 1.5 & & & 1.3 & 1.6 & & & \\
\hline \multirow{2}{*}{ Washington, DC } & 45 & 9 & 20 & 8 & 68 & 5 & 3 & 36 & 74 & 14 & 9 & 294 \\
\hline & & & & & 2.2 & & & & 1.8 & & & \\
\hline \multirow{2}{*}{ Houston, TX } & 35 & 20 & 34 & 11 & 29 & 24 & 13 & 11 & 15 & 18 & 11 & 229 \\
\hline & & & 1.2 & & 1.2 & 1.7 & 1.8 & & & 1.6 & 1.3 & \\
\hline \multirow{2}{*}{ San Antonio, TX } & 30 & 12 & 21 & 16 & 37 & 16 & 5 & 17 & 31 & 24 & 9 & 226 \\
\hline & & & & 1.5 & 1.6 & & & & 2.1 & & & \\
\hline \multirow{2}{*}{ San Francisco, CA } & 35 & 15 & 16 & 7 & 29 & 6 & 4 & 54 & 38 & 13 & 3 & 222 \\
\hline & & & & & 1.2 & & & 2.2 & 1.2 & 1.2 & & \\
\hline \multirow{2}{*}{ Montreal, QC } & 16 & 24 & 56 & 11 & 7 & 13 & 10 & 15 & 23 & 10 & 9 & 198 \\
\hline & & & 2.2 & 1.2 & & & 1.6 & & & & 1.2 & \\
\hline \multirow{2}{*}{ Ottawa, ON } & 29 & 12 & 50 & 6 & 14 & 9 & 9 & 13 & 15 & 10 & 9 & 179 \\
\hline & & & 2.2 & & & & 1.6 & & & & 1.3 & \\
\hline \multirow{2}{*}{ Vancouver, BC } & 24 & 26 & 46 & 11 & 6 & 8 & 1 & 17 & 22 & 11 & 5 & 177 \\
\hline & & 1.3 & 2.0 & 1.3 & & & & & & 1.2 & & \\
\hline \multirow{2}{*}{ Austin, TX } & 14 & 13 & 22 & 4 & 35 & 13 & 7 & 16 & 21 & 16 & 3 & 169 \\
\hline & & & & & 2.0 & 1.2 & 1.3 & & & 1.9 & & \\
\hline \multirow{2}{*}{ Minneapolis, MN } & 23 & 19 & 14 & 3 & 12 & 18 & 8 & 8 & 23 & 14 & 6 & 151 \\
\hline & & & & & & 1.9 & 1.7 & & & 1.9 & 1.1 & \\
\hline \multirow{2}{*}{ Phoenix, AZ } & 18 & 12 & 17 & 8 & 17 & 15 & 5 & 10 & 21 & 9 & 3 & 135 \\
\hline & & & & 1.2 & 1.2 & 1.7 & 1.2 & & & 1.3 & & \\
\hline Total (Top 25 Cities) & 1129 & 827 & 944 & 355 & 781 & 473 & 233 & 813 & 1054 & 374 & 281 & 7437 \\
\hline
\end{tabular}

Notes: (a) Trade Fair Location Quotients $\geq 1.2$ bolded ( $\geq 2.0$ highlighted).

(b) Industrial Sector abbreviations: BZ = Professional Business Services; $\mathrm{CG}=$ Consumer Goods and Retail Trade; CS = Consumer Services, Sports, Travel, Entertainment, and Art; FD = Food; $\mathrm{GV}=$ Government, Public, and Non-Profit Services; HM = Construction, Building, Home, and Repair; ID = Industrial/Heavy Machinery and Finished Business Inputs; IT = Information Technology and Communications; $\mathrm{MD}=$ Medical and Health Care; RM = Raw Materials and Science; $\mathrm{TX}=$ Transportation.

Source: CEIR, 2005 


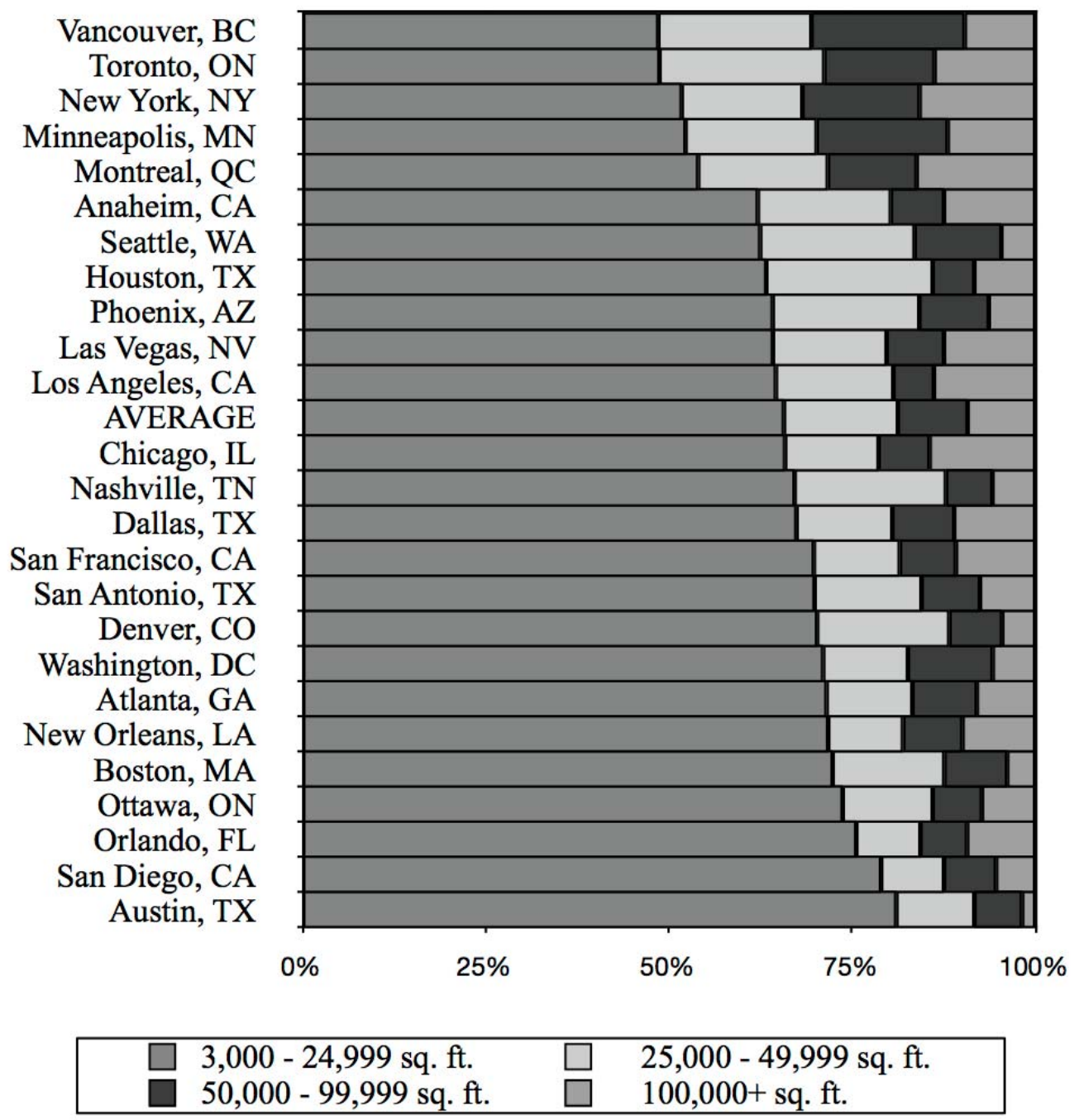

Figure 4: Number of Trade Fairs by Size Category in the Top 25 North American Trade Fair Cities, 2005 (Source: CEIR, 2005) 


\section{Notes}

${ }^{1}$ Our focus is on U.S. and Canadian trade fairs, which are comparable in terms of their development stage.

2 Both trade fairs and conventions are often held in the same trade fair, convention, conference, or exhibition spaces, which is why we do not strictly distinguish these different spaces. Conventions and conferences are regular, highly mobile events that are centered on professional presentations and typically take place in different cities, while exhibitions and trade fairs (or trade shows) are focused on the exhibit of products and technologies. In contrast to exhibitions, which are singular events, trade fairs are periodic events that provide a regular platform for observation, learning, and communication between the firms of a value chain.

3 The importance of such temporary spaces has also been recognized in studies of periodic markets in the context of less developed economies (McKim, 1972; Udosen and Adams, 2009). Even though medieval trade fairs and $19^{\text {th }}$ century world exhibitions were already more than just events where products were displayed or sold (Piore and Sabel, 1984), the aspect of knowledge creation was not a key aspect in former academic debates.

${ }^{4}$ Global buzz differs between different types of trade fairs. It is clearly strongest in international fairs, but is also present to some degree in less wide-ranging events.

${ }^{5}$ It is generally difficult to study trade fairs because available data is incomplete, definitions differ between countries, and central databases usually do not exist (Kresse, 2003; AUMA, 2009a).

${ }^{6}$ We conducted one-hour exploratory interviews with trade fair organizers in Las Vegas and Toronto.

${ }^{7}$ In comparison, the Mexican trade fair industry developed much later than that in the U.S. and Canada, triggered by globalization processes and the opening of the Mexican market since the 1980s. The respective events have remained relatively small 
with typically less than 50,000 square feet. According to AUMA (2004b), an average Mexican trade fair had about 100 exhibitors and 7,500 attendees.

${ }^{8}$ Such misjudgment is even more problematic in the case of singular events such as World Exhibitions, which require huge investments (see Diez and Kramer, 2000; Kaiser, 2002). However, there are also examples of trade fairs serving to alleviate economic downturns associated with deindustrialization. For example, High Point Market - a bi-annual international furniture trade fair that attracts over 85,000 participants - has helped the city of High Point, North Carolina adapt to the decline of the local furniture manufacturing industry (High Point Market, 2010).

${ }^{9}$ It appears that this trend has not been reversed through the 2008 global financial crisis. Although small and medium-sized regional fairs seem to have suffered, the large international fairs have been less affected, as the example of Las Vegas exemplifies (Velotta, 2009).

10 While the building, construction, and home repair sector saw the largest growth, this was also related to a change in the way the CEIR data was collected in 2004.

11 Our research on the nature of these events shows that these are usually not meeting places for highly-specialized global communities.

12 TFLQs are defined as ratios of the local importance of a sector relative to its importance in the top 25 North American cities overall. These quotients are calculated as TFLQ $=\left(e_{i} / e\right) /\left(E_{i} / E\right)$ where $e_{i}$ is a city's number of trade fairs in sector $i$; $e$ is the total number of trade fairs in the city; $E_{i}$ is the total number of trade fairs in sector $i$; and E the total number of trade fairs in the overall data set. It is important to note that this data set only covers the top 25 trade fair cities in North America, so the TFLQs are measured against those cities, and not the entire set of trade fairs in North America.

13 The consumer goods sector is made up of fairs where retail products are presented by manufacturers to retail store buyers. In the case of Montreal, the high TFLQ of this sector may also be related to the vibrant cultural economy in the city.

${ }^{14}$ Media reports suggest that revenues from trade fair attendees are possibly even larger than those from gambling (Spillman, 2007). Moreover, employment effects of 
large international trade fairs are substantial, adding some direct 2,000 jobs to the regional economy - not including the indirect employment effects.

15 However, trade fair officials at the MTCC raise doubts over how many local firms actually attend larger international events held in the city (Interview with MTCC officials, July 2009). 